\title{
DOES AUDITOR INDEPENDENCE, SKEPTICISM, AND PROFESSIONALISM INFLUENCE AUDIT QUALITY?
}

\author{
Putri Puspitarani $^{1}$, Supeni Anggraeni Mapuasari ${ }^{2}$ \\ ${ }^{1}$ Faculty of Business, President University \\ Email: putripuspitarani@gmail.com \\ ${ }^{2}$ Faculty of Business, President University \\ Email: supeni@president.ac.id
}

Masuk : 30-03-2020, revisi: 10-06-2020, diterima untuk diterbitkan : 10-06-2020

\begin{abstract}
ABSTRAK
Riset ini menyajikan bukti empiris faktor-faktor yang mempengaruhi kualitas audit yang bersumber dari kognisi auditor. Faktor kognisi yang diujikan antara lain independensi, skeptisme, dan profesionalisme. Independensi didefinisikan sebagai kemauan auditor untuk netral dan tidak bias dalam mengambil keputusan. Skeptisme adalah kemauan auditor untuk mempertanyakan dan melakukan prosedur audit tambahan ketika terjadi keraguan dalam penentuan pertimbangan audit. Profesionalisme merepresentasikan pemahaman dan sikap auditor atas hak dan kewajibannya yang diatur oleh organisasi profesi. Untuk menguraikan logika hipotesis, riset ini menggunakan teori disonansi kognitif. Auditor tentu mengalami berbagai dinamika dalam menjalankan tugasnya. Dinamika ini terkadang mengandung ketidaksesuaian antara kognisi yang dimilikinya dengan apa yang ditemukannya. Dalam kondisi tersebut, penelitian ini menduga bahwa auditor yang memiliki rasa independensi yang tinggi akan lebih mampu menghasilkan kualitas audit yang baik. Auditor dengan skeptisme yang semakin tinggi tentu akan mau untuk mengeluarkan upaya tambahan demi meraih kualitas audit yang sesuai. Sementara itu, profesionalisme mampu mendukung kemantapan auditor dalam mengupayakan kualitas audit yang tinggi. Dengan menggunakan metode survei yang disebarkan pada para auditor di kantor akuntan publik di kota jakarta, riset ini menemukan bahwa independensi, skeptisme, dan profesionalisme secara signifikan mendukung persepsi kualitas audit. Ini artinya, kantor akuntan publik dapat mempertimbangkan faktor-faktor ini dalam perumusan kebijakan rekrutmen dan pelatihan.
\end{abstract}

Kata Kunci: independensi auditor, skeptisme auditor, professionalisme auditor, kualitas audit

\begin{abstract}
This research presents empirical evidence of the factors that influence audit quality sourced from auditor cognition. Cognition factors tested included independence, skepticism, and professionalism. Independence is defined as the auditor's willingness to be neutral and not biased in making decisions. Skepticism is the auditor's willingness to question and carry out additional audit procedures when there is doubt in determining audit considerations. Professionalism represents the auditor's understanding and attitude towards his rights and obligations governed by professional organizations. To outline the logic of the hypothesis, this research uses the theory of cognitive dissonance. Auditors naturally experience various dynamics in carrying out their duties. This dynamic sometimes contains a mismatch between the cognition it has and what it finds. Under these conditions, this study suspects that auditors who have a high sense of independence will be better able to produce good audit quality. Auditors with increasing skepticism will certainly want to spend additional effort to achieve appropriate audit quality. Meanwhile, professionalism can support the stability of auditors in seeking high audit quality. Using a survey method distributed to auditors at public accounting firms in Jakarta, this research found that independence, skepticism, and professionalism significantly support the perception of audit quality.
\end{abstract}

Keywords: auditor independence, auditor skepticism, auditor professionalism, audit quality

\section{INTRODUCTION}

Although the financial statement audit held an important role in the business firm, audit quality is problematic and still difficult to measure (Power, 1991). Auditors express an opinion on the fairness of financial statements, and it uses for the users of financial statements to gain assurance that the data are being reported, properly measured, and fairly presented. However, it is important to research into perceptions of audit quality because it determines the credibility of the audit report (Shockley, 1981). Both definition and measurement of audit quality is still 
conflicting and not yet agreed among researchers (Ghany, 2012). Sutton (1993) summarize that the conflicting roles of participants in the audit market create disagreement on the criteria of audit quality.

The audit is mentioned to be qualified if it can ensure the financial statements are free from material misstatement, both due to error or fraud (DeAngelo, 1981). Thus, DeAngelo (1981) addresses the importance of auditor independence for these objectives. IFAC, (2004) summarize that Audit quality is the most fundamental characteristic of international auditing standards. Practitioners require high-quality audits that help the companies comply with legal and professional requirements. Audit quality is strongly related to the professional body and its standards (Ehlen \& Welker, 1996). For auditors, clients, and third parties, Audit failures have economic consequences. However, Palmrose (1988) stated that litigation case between the auditor and the companies is still rare.

Global Financial Crisis nowadays has seen policymakers once again focus attention on the importance of an effective audit function as a key component in effective capital markets and attempt to identify key drivers of audit quality. These investigations and regulatory changes make it clear that there has been considerable dissatisfaction with the effectiveness of corporate governance, the quality of the audit process and the roles of auditors and auditing. In response, regulators and the accounting profession have taken a number of policy measures to improve audit quality in both fact and appearance. Recent examples include the SEC's proposed ban on audit firms undertaking non-audit services (NAS) and the rapid adoption of SOX following Enron ${ }^{\text {ee }}$ collapse (Francis, 2004). In Indonesia, during 2019 two big entities suffered from financial collaps due to fraudulent reporting. These two big entities are Jiwasraya and Garuda Indonesia. Their financial statements are materially misstated and not reflecting the real value of the companies (Rahma, 2019).

The audit primarily purposes to meet the needs of users of financial information such as investors, creditors, prospective creditors and government agencies (Boyton \& Kell, 2006). As a profession which people give their trust to, it's required public accountants to pay attention to the result of audit quality, but the accounting scandal that occurred in major U.S. companies such as Enron, WorldCom, has damaged public trust and credibility that resulted in substantial criticism of the business (Frohnen and Clarke, 2002).

Enron case is one evident that accounting ethics is required (especially the application of professional ethical standards in the form of auditor independence. For that case, auditor independence became an important issue for the public accounting profession. Auditors have taken apart on many big financial scandals both in private sectors and in the public sector, many financial cases in private sectors may cause bankruptcy. For example the cases of On-Tel, HIH in Australia, Waste Management dan Xerox in America, Parmalat in Italia, Harris Scarfe, and many more (Cohen \& Bennie, 2006). In Indonesia, the annual potential loss of the Government is around 100 trillion rupiahs. It is caused by system inefficiency and fraud. This data was published by SAI. Hamilton (2005) suggests that one of the things that can hinder the ability of public accounting to provide a high-quality audit is a long period relationship between the client and the accountants that can increase the intimacy occurring between the public accountant and the client. 
Furthermore, a Public Accounting firm that has a big name is seen as an auditor that will generate audit quality levels that exceed the minimum requirements of professionalism compared to the quality of the Public Accountant Office that does not have a well-known name (Hamilton, 2005). On the other hand, when related to the reputation, the audit quality is one of the main factors that determine the reputation of Public Accounting firm (Baotham; 2009), in which the office needs to make efforts to improve the quality of the resulted audit because if it is not capable to provide the high-qualified audit results, the reputation in the community will be threatened. For Public Accounting firm, reputation is a very important factor, because if the office has a good reputation many companies will have an interest in using their services, for the results of the audit of the office will obtain a high level of trust from the community (Baotham, 2009).

In those cases, auditor independence, auditor skepticism, and auditor professionalism must be questioned. One of the major causes of financial scandals is the unethical behavior of auditors (McPhail and Walters, 2009). From a skepticism point of view, the failure to gather enough evidence may cause the failure to make the right audit judgment (Beasley et al. 2001). As the consequent in gaining an understanding of factors that affect perceptions of audit quality is important because it can help regulators and the accounting profession to formulate policy based on empirical evidence rather than on a priori assumptions (Shaub 1996). Researchers have taken some factors that can affect Audit Quality, such as Auditor Independence, Auditor professionalism, and Auditor skepticism.

This research is aimed to examine the influence of auditor independence, skepticism, and professionalism to perceived audit quality. This research contributes to empirical findings gained from Auditors surrounding Jakarta to enrich both existing literature and practical guidelines for public accounting firms. Public accounting firms may address the finding to get any insight into designing recruitment policy and training agendas. Logical explanations on the hypothesis are using the framework of cognitive dissonance theory (Festinger, 1957).

\section{LITERATURE REVIEW}

\section{Cognitive Dissonance Theory}

Teory of cognitive dissonance explains human interaction in facing coginition and dissonance. Naturally, every human being is having several cognitions representing their preferences, believes, and predisposition on them self image and surrounding society. They value the society based on these cognitions. Their cognitions are built from knowledge, experience, and personal perception. When personal cognitions conflicts with other contradicting cognitions and facts, human have several options to do. First, they may change their previous cognitions and follow the other new cognition or facts. This first choice is calling for behaviour and adaptation to accept different things in self. Second, they may choose to defend their cognition over that conflicting one. Third, they may add their cognitions and try to blend up their cognition with the new ones. Second and third options are inline with the phenomena of auditor willingness to gather more evidences before taking decision on many audit conflicting dillemas. The theory of cognitive dissonance is introduced by Festinger (1957).

Based on cognitive dissonance theory, when auditor found a misstatement, he/she will face a dilemma whether to dislose or not, how detail the disclosure is, and what is the right audit judgement. Auditor may face the dissonance with keeping in a silent, not dislosing the finding. The second choice is to keep attention to the issue by gathering additional evidence or 
procedures. Those actions are done with a purpose of being able to take the best judgement. Taking the best judgement from valid and complete evidence will reduce the auditor dissonance.

\section{Auditor Independence}

Richard (2006) conducted a study to identify the independence of public accountant, where he tried to examine why it is difficult for auditor to be an independent in conducting the audit process with a case study on several companies in France. The results showed that the lower the level of independence will lead to audit quality decrease. Furthermore, Arens et al. (2008) states that public accountants strive to maintain a high level of independence to maintain the trust of users who rely on their reports. The threat toward independence does not only happen when public accountant audit but also potentially affects the audit opinion (Dopuch et al., 2003).

Auditor independence is important because it has an impact on the audit quality. DeAngelo (1981) suggests that audit quality is defined as the probability that (1) the auditor will uncover the breach and (2) report the breach. If the auditor does not remain independent, auditor will be less likely to report the irregularities and hence, the audit quality will be impaired. Auditor independence defined as the refusal of the auditor to support any detected misstatements and standing against client's attempts to influence his/her audit report (Nichols and Price, 1976). The American Institute for Certified Public Accountants (AICPA) in its code of ethical conduct which revolves about the idea that an auditor has a primary responsibility for the public; in its fourth principle, it classified primary responsibility for the public; in its fourth principle, it classified that objectivity and independence should be maintained by the auditor and that independence should be exercised both in fact and in appearance while providing an audit or any other attestation service (Collins and Schultz, 1995).

H1: auditor independency has a positive significant influence towards Audit quality.

\section{Auditor Profesional Skepticism}

Skepticism is defined as willingness to gather additional evidence before taking a decision. In auditing context, it is an attitude that includes a questioning mind, a critical assessment of evidence, the ability to detect fraud, the opposite of trust, be more conservative in audit judgement, and maintaining daubt on evidence provided by client (Hurtt et al., 2013). Skepticism encourages auditor to be more able to find materially mistatement during audit fieldwork, both due to error and fraud (Hurtt et al., 2013). Nevertheless, whether skepticisism will enhance audit quality or not is still in discussion. Bowling, et al. (2015) stated that skepticism will not enhance audit quality when the auditors are having perception that they are no longer be retained in the company again in the future. Thus, shorter auditor rotation may reduce audit skepticism.

From cognitive dissonance theory point of view, auditors who realize the importance of moral intensity understands the consequence of audit issue. He/she also realized the consequences of audit action taken. Because of this awareness, he/she will be more carefull to judge. This carefullness will force him/her to be more skeptical. The first three characteristics of professional skepticism (a questioning mind, suspension of judgment, searchs for knowledge) relate to the way an auditor examines evidence. Nelson (2009) discusses this lack of precision in the use of the term "professional skepticism" and categorizes professional standards and academic research as holding either a neutral position, a presumptive doubt position, or a position of Bayesian unbiasedness when discussing professional skepticism. More recently, Hurtt (2007) has expanded and tested an auditing-focused skepticism scale. Hurtt (2007) bases the scale on six separate characteristics of skeptics that are distinct from knowledge and ethics. It supports those characteristics from the philosophy literature and auditing standards. 
Auditor skepticism can be observed from neutral or bias poin of view. From neutral view, auditor may not being skeptic to client. Auditor should be critical, but still positive thinking. On the bias side, auditor must be skeptic and believe on the possibility of any material misstatements done by clients (Nelson, 2009; Brown-Liburd, 2013). The more skeptical, the more willingness to gather related evidence (Peecer, 1996; Nelson, 2009). More auditor skepticism reassure their assertion and minimize the failure of detecting error (McMillan \& White, 1993).

H2: Auditor skepticism has a positive significant influence towards audit quality

\section{Auditor Professionalism}

Based on cognitive dissonance theory could explain that the incidence inconsistency in self auditors to follow or not to follow the majority of code of conduct, can affect his professionalism as auditors as well as differences in individual perceptions about the ethical or unethical can cause disharmony. Professional person conclude as a person who commits to a full time job and live off the job by relying on the expertise and high skill with being highly loyal to the job (Keraf, 1998). Therefore, people who are professionals or known by to have professional attitude are people doing a job for experts in the field by taking all the time, effort and attention to the job along with a personal commitment to their work. Previous research Hudiwinarsih (2005) has tested and conclude that professionalism of auditor can affect audit quality.

\section{H3 : Auditor professionalism has a positive significant influence towards audit quality.}

\section{Model Penelitian}

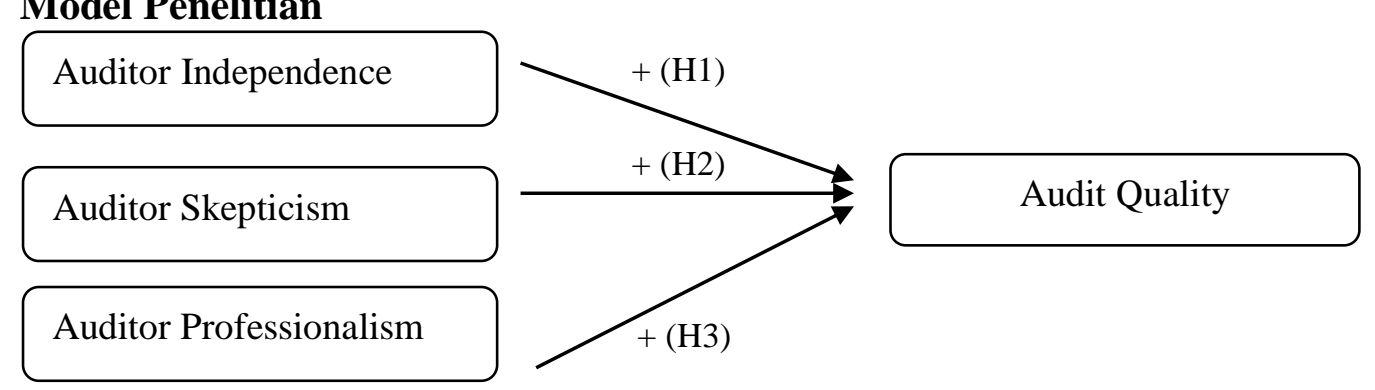

\section{RESEARCH METHOD}

This research use survey method. Questionnaires were spread of in big four and second tier public accounting firm in Jakarta. The respondent criteria of this research is auditor who is currently active in audit engagement. From 111 questionnaires, only 70 numbers were back,. The response rate is $63,7 \%$. There are fourth common ways to diminish bias. Firstly, researchers guarantee the confidentiality of all information given by respondents. Secondly, researched is not directly interacted with the respondents. Third, to prevent bias we randomize questionnaire and not exlicity explain variable researched. In last way, the arrangement of questions follows the most convenience sugestion. The original questionnaire in English, then translated in the language Indonesia carefully. The object research that used in this study is external auditor who works in public accounting firm. Therefore, the respondent in thus research is individual.

\section{Operational Definition}

Auditor independency defined as the refusal of the auditor to support any detected misstatements and standing against client's attempts to influence his/her audit report (Nichols and Price, 1976; $\mathrm{Lu}, 2005)$. Respondents will be given questionnaire about the importance of the independent auditor and the importance of being neutral and not biased during the audit process. Auditor independency is measured with an instrument developed by Tjun (2012). Professionalism is a combination of skills, rights and obligations of professional values in general. Respondents will 
be given a questionnaire about the importance of the professionalism of auditors and their effects on audit quality. Auditor professionalism is measured with an instrument used by Wahyudi (2006). Definition used in this study based on Hurtt (2007) auditor skepticism in terms of various characteristics of skeptics (e.g., a questioning mind, suspension of judgment, self- confidence) that focus more on having and pursuing doubt than on a particular direction of doubt. Professional skepticism is measured with an instrument developed by Hurtt (2010).

We are using SPSS software to analyse the data. The statistical instruments are factor analysis (for validity and reliability test) and multiple regression (for hypothesis testing). The regression formula is below:

$A Q=\alpha+\beta_{1} I+\beta_{2} S+\beta_{3} P+e$

Notes:

AQ : perceived audit quality

I : perceived auditor independence

$\mathrm{S}$ : auditor skepticism score

$\mathrm{P}$ : perceived auditor professionalism

E : residual error

\section{RESULTS AND DISCUSSION Validity and reliability test}

The validity test in this research is using Bivariate Pearson correlation. Test is using two side tests with level of significance 0.05 . The criteria is If $r$ count $\geq r$ table ( 2 side test with sig. 0.05) the instrument or questionnaire items have significant correlation to the total score (declared valid). If count $<\mathrm{r}$ table ( 2 side test with sig. 0.05 ) the instrument or questionnaire items do not have significant correlation to the total score (declared invalid). All questions reponded by the respondents are tested and passed the validity measures. Hurt (2010) reliability test can be used to measure the stability and consistency measuring instrument that bias can be minimized. This consistency can be measured by Cronbach alpha values. Cronbach alpha minimum criteria allowed is above 0.60 (Gudono, 2011). From the data processing SPSS, the three variables have met the minimum requirement so the Cronbach alpha audit quality measures can be said to be reliable.

Table 1. Reliability test

\begin{tabular}{ccc}
\hline Variable & Cronbach alpha & Description \\
\hline Audit quality &, 819 & Reliable \\
\hline Auditor independence &, 772 & Reliable \\
\hline Auditor skepticism &, 745 & Reliable \\
\hline Auditor professionalism &, 717 & Reliable \\
\hline
\end{tabular}

Table 2. Respondent Profile

Source: Primary Research Data

\begin{tabular}{|c|c|c|c|}
\hline & Description & $\begin{array}{l}\text { Number } \\
\text { (Person) }\end{array}$ & Percentage \\
\hline $\begin{array}{c}\text { Gender } \\
1 . \\
2 .\end{array}$ & $\begin{array}{l}\text { Man } \\
\text { Woman }\end{array}$ & $\begin{array}{ll}\text { 1. } & 43 \\
\text { 2. } & 27\end{array}$ & $\begin{array}{l}\text { 1. } 61 \% \\
\text { 2. } 39 \%\end{array}$ \\
\hline $\begin{array}{c}\text { Position } \\
1 . \\
2 . \\
3 . \\
4 . \\
\end{array}$ & $\begin{array}{l}\text { Partner } \\
\text { Manager } \\
\text { Senior Auditor } \\
\text { Junior Auditor }\end{array}$ & $\begin{array}{ll}\text { 1. } & 4 \\
\text { 2. } & 6 \\
\text { 3. } & 22 \\
\text { 4. } & 38\end{array}$ & $\begin{array}{ll}\text { 1. } & 6 \% \\
\text { 2. } & 9 \% \\
\text { 3. } & 31 \% \\
\text { 4. } & 54 \% \\
\end{array}$ \\
\hline
\end{tabular}




\begin{tabular}{|c|c|c|}
\hline \multicolumn{3}{|l|}{ Last Education } \\
\hline 1. $\mathrm{D} 3$ & 1. 0 & 1. $0 \%$ \\
\hline 2. $\mathrm{S} 1$ & 2. 48 & 2. $68 \%$ \\
\hline 3. $\mathrm{S} 2$ & 3. 20 & 3. $28 \%$ \\
\hline 4. $\mathrm{S} 3$ & 4. 2 & 4. $4 \%$ \\
\hline \multicolumn{3}{|l|}{ Working Experience } \\
\hline 1. $<5$ years & 1. 33 & 1. $47 \%$ \\
\hline 2. 5-10 years & 2. 22 & 2. $31 \%$ \\
\hline 3. $11-15$ years & 3. 10 & 3. $14 \%$ \\
\hline 4. $16-20$ years & 4. 5 & 4. $8 \%$ \\
\hline \multicolumn{3}{|c|}{ Case resolved within 1 year } \\
\hline 1. Nothing & & 1. $0 \%$ \\
\hline 2. 1-2 case & 2. 0 & 2. $0 \%$ \\
\hline 3. 3-4 case & 3. 27 & 3. $38 \%$ \\
\hline 4. $>5$ case & 4. 43 & 4. $62 \%$ \\
\hline
\end{tabular}

Table3. Determination analysis

\begin{tabular}{|c|c|c|c|c|}
\hline \multicolumn{5}{|c|}{ Model Summary } \\
\hline Model & $\mathrm{R}$ & R Square & $\begin{array}{l}\text { Adjusted R } \\
\text { Square }\end{array}$ & $\begin{array}{l}\text { Std. Error of the } \\
\text { Estimate }\end{array}$ \\
\hline 1 & ,990 a & ,980 &, 979 & ,05809 \\
\hline
\end{tabular}

Based on the table 4.7, adjusted $\mathrm{R}^{2}$ showed at level 0,979 which means all the independent variables (Auditor Independency (X1), Auditor skepticism (X2), Auditor professionalism (X3)) that used in this research have a contribution percentage for $97,9 \%$ in order to explain the dependent variable quality of audit (Y).

\section{Hypothesis testing}

\begin{tabular}{|c|c|c|c|c|c|c|}
\hline \multirow{2}{*}{\multicolumn{2}{|c|}{ Model }} & \multicolumn{3}{|c|}{ Table 4. Regression T-test Results } & \multirow{3}{*}{$\mathrm{t}$} & \multirow{3}{*}{ Sig. } \\
\hline & & \multicolumn{2}{|c|}{ Unstandardized Coefficients } & \multirow{2}{*}{$\begin{array}{c}\begin{array}{c}\text { Standardized } \\
\text { Coefficients }\end{array} \\
\text { Beta } \\
\end{array}$} & & \\
\hline & & $\mathrm{B}$ & Std. Error & & & \\
\hline \multirow{4}{*}{1} & (Constant) &, 005 &, 075 & & ,072 & ,943 \\
\hline & Independence & ,557 &, 032 & ,588 & 17,220 &, 000 \\
\hline & Skepticism & 081 &, 029 &, 092 & 2,776 &, 007 \\
\hline & Professionalism & ,361 & ,048 & 377 & 7,597 & 000 \\
\hline
\end{tabular}

The result of testing for the first hypothesis (H1) which states that auditor independency has a significant effect on quality audit was confirmed on the table 4 . That table showed that the score that the score of regression coeficient for auditor independency (X1) is 0.557 and $t$ score is 17,220. So, the first hypothesis (H1) which states that auditor independency has a significant effect on quality of audit is accepted. It can also be seen from coefficient regression score which is significance at level 0.05 with $\mathrm{P}$ value of $0,000(0.05>0,000)$. Furhermore, The result of testing for the second hypothesis $(\mathrm{H} 2)$ which states that auditor skepticism has a significant effect on quality audit showed that the score that the score of regression coeficient for auditor independency (X2) is 0.081 and t score is 2.776 . It can also be seen from coefficient regression score which is significance at level 0.05 with $\mathrm{P}$ value of $0,007(0,007<0.05)$. The result of testing for the third hypothesis (H3) which state that auditor professionalism has a significant effect on quality audit showed that the score that the score of regression coeficient for auditor independency (X3) is ,361 and t score is 7,597 The p value also showed the significance value which is 0,000 . 
Then, the result of testing for the third hypothesis (H3) which state that auditor professionalism has a significant effect on quality audit showed that the score that the score of regression coeficient for auditor independency (X3) is ,361 and t score is 7,597 The p value also showed the significance value which is 0,000 .

\section{SUMMARY AND RECOMMENDATION}

This study aims to determine the influence of auditor independency, auditor skepticism, and auditor professionalism on the audit quality, which used the 111 auditors in public accounting firms in DKI Jakarta as the sample of research. According to the results of the study the researcher define that auditor independency, auditor skepticism, and auditor professionalism partially has a significant influence toward audit quality. This three variables simultaneously influence towards audit quality. The findings of our researches adress the importance of those three variables to be discussed and maintained during recruitment and training programs.

Other researcher can enrich more variables for the test of the research for example auditor integrity, so the test will be more accurate and valid. Then, further research can enlarge the sample, it can be not just centered in one area and adds more accounting public firm outside DKI jakarta in order to makes the good eksternal validity. This research is usefull to auditor to maintain their auditor behaviour in order to maintain the audit quality. Because based on this research, the Auditor Independency, Auditor skepticism, and Auditor Professionalism has significance influence to the audit quality. In addition, future researcher can use other method like qualitative method. So, the researcher can confirm the real condition of the research.

Future research might improve this research by finding moderating and mediating variable that might reduce or improve audit quality. Nowadays era, auditor is facing crucial issues, such as pandemic Covid-19 era. Audit profession have to rearrange another back up system to maintain audit quality in todays era. Internet based audit is a must have choice. It is remains unclear whether this pandemic will enable the auditor to maintain audit quality even if they are having enough score in professionalism, independence, and skepticism. Another psychological and hard skill variable have potential major influence in defining audit quality.

\section{Acknowledgement}

The researchers would like to acknowledge President University for supporting this study through internship experience in the public accounting firms, so the researchers are able to reach proper respondents. We also thanks to all auditors responding our questionaires.

\section{REFERENCE}

Baotham, S. (2009). Audit Independence, Quality and Credibility: Effect on Reputation and Sustainable Success of CPAs in Thailand. International Journal and Business Research. Vol 9.

Bowling, KO., Hobson, JL., Piercy, DM. (2015). The Effect of Auditor Rotation, Proffesional Skepticism, and Interactions with Managers on Audit Quality. The Accounting Review, 90 (4).

Brown-Liburd, Hellen, L., Cohen, J.R., and Trompeter, G. (2013). Effect of Earning Forecasts and Heightened Professional Skepticism on the Outcomes of Client-Auditor Negotiation. Journal of Business Ethics, 116:311-325.

Cohen, J.R and Bennie, M. (2006). The Applicability of a Contingent Factors Model to accounting Ethic Research. Journal of Business Ethics, 68(1): 1-18. 
Collins, A. and Schultz, N. (1995). A Critical Examination of code of Professional Conduct. Journal of Business Ethics, Vol. 14, pp. 31-41

DeAngelo, L. (1981a). Auditor Size and Audit Quality. Journal of Accounting and Economics 3 (3): 183-199

DeAngelo, L. E. (1981b). Auditor Independence, 'Low Balling', and Disclosure Regulation. Journal of Accounting and Economics 3: 113-127.

Dopuch, N., R. R. King, and R. Schwartz. (2003). Independence in appearance and in fact: An experimental investigation. Contemporary Accounting Research 20 (1): 79-114.

Ehlen, C. R., \& Welker, R. B. (1996). Procedural Fairness in the Peer and Quality Review Programs. Auditing: A Journal of Practice \& Theory, 15(1), 38-52.Ethical, Not a Legal, Problem, In USA Today Magazine.ethics. Inquiry-An Interdisciplinary. The Journal of Philosophy 12 (1): 66-104.

Festinger, L. (1957). A theory of Cognitive Dissonance. Stanford University Press.

Francis, J. (2004). What do we know about audit quality?. The British Accounting Review 34 (4): 345-368.

Frohnen, Clarke (2002). The Impact of Regulations on Auditor Fees: Evidence from the Sarbanes-Oxley Act. Working Paper Series, City University of New York, pp. 2-45.

Ghany, Abdel K. (2012). Do Government Audits Need Engagement Quality Reviews?. The Journal of Government Financial Management, 61(1), 48-4.

Gudono. (2011). Analisis Data Multivariat. Vol.1. Yogyakarta

Hamilton, J. Ruddock, C., Stockes, D. \& Taylor, S. (2005). Audit Partner Rotation, Earnings Quality and Earnings Conservatism. Working papers series of the University of New South Wales.

Hudiwinarsih, Gunasti. (2005). Pengaruh Pengalaman Terhadap Profesionalisme dan Pengaruh Profesionalisme terha- dap Kinerja, Komitmen Organisasi, kepuasan Kerja, dan Turnover Inten- tions. Ventura.

Hurtt, R. K. (2007). Professional skepticism: An audit specific model and measurement scale. Working paper, Baylor University.

Hurtt, R.K. (2010). Development of a Scale to Measure Professional Skepticism. Auditing: A Journal of Practice and Theory, 29(1):149-171.

Hurtt, R.K., Brown-Liburd, H., Earley, C.E., Krishnamoorthy, G. (2013). Research on Auditor Skepticism: Literature Synthesis and Opportunities for Future Research. Auditing: A Journal of Practice \& Theory: 32 (1).

Keraf, Sonny A. (1998). Etika Bisnis : Tuntutan dan Relevansinya. Edisi Baru. Yogyakarta, 3353

McMillan, J.Jand White, R.A. (1993). Auditors' Belief Revision and Evidence Search: The Effect of Hypothesis Frame, Confirmation, and Professional Skepticism. The Accounting Review, 68 (3): 443-465.

McPhail, K. dan Walters, D. (2008). Accounting and Busniess Ethics. Routledge, Taylor \& Francis Group, New York.

Nelson. (2009). "A Model and Literature Review of Professional Skepticism in Auditing”. A Journal of Practice and Theory, 28 (2):1-34

Nichols, D.R. and Price, K.H. (1976), "The auditor-firm conflict: an analysis using concepts of exchange theory", The Accounting Review, Vol. 51 No. 2

Palmrose, Z-V. (1988). An analysis of auditor litigation and audit service quality. The Accounting Review 63 (1): 55-73.

Power, M. (1991). Educating accountants: Towards a critical ethnography. Accounting, Organizations and Society 16 (4): 333-353.

Rahma, A. (2020). BPK: Jiwasraya Manipulasi Laporan Keuangan dari Rugi Jadi Laba di 2006. 
Richard C (2006). Why an Auditor can't be Competent and Independent: A French Case Study. European Accounting Review. 15: 153-179.

Shaub, M. K. (1996). Trust and Suspicion: The Effects of Situational and Dispositional Factors on Auditors' Trust of Clients. Behavioral Research in Accounting 8: 154-174.

Shockley, R. (1981), "Perceptions of Auditor Independence", The Accounting Review, 56 (4): PP 785-800.

Sutton, S. G. (1993). Toward an Understanding of the Factors Affecting the Quality of the Audit Process. Decision Sciences, 24

Wahyudi. 2006. Pengaruh Professionalisme Auditor Terhadap Tingkat Materialitas Dalam Pemeriksaan Laporan Keuangan. Simposium Nasional Akuntansi. 